\title{
ON THE RIESZ IDEMPOTENT OF CLASS A OPERATORS
}

\author{
A. UCHIYAMA AND K. TANAHASHI
}

Abstract. In this paper, we show that if $T$ is a class $A$ operator and $\lambda$ is a non-zero isolated eigenvalue of $\sigma(T)$, then $E \mathscr{H}=\operatorname{ker}(T-\lambda)=\operatorname{ker}(T-\lambda)^{*}$, where $E$ is the Riesz idempotent with respect to $\lambda$. In this case, $E$ is self-adjoint, i.e, it is an orthogonal projection.

Mathematics subject classification (2000): 47A10, 47B20. operator.

Key words and phrases: Riesz idempotent, $p$-hyponormal operator, class A operator, paranormal

\section{REFERENCES}

[1] A. AluthGe AND D. WANG, An operator inequality which implies paranormality, Math. Inequal. Appl., 2 (1999), 113-119.

[2] A. AluThGe AND D. WANG, w-hyponormal operators, Integr. Equat. Oper. Th., 36 (2000), 1-10.

[3] T. ANDO, Operators with a norm condition, Acta. Sci. Math. (Szeged), 33 (1972), 169-178.

[4] M. CHO AND T. HuRUYA, $p$-hyponormal operators $(0<p<1 / 2)$, Comment. Math., 33 (1993), 23-29.

[5] M. СHO, M. ITOH AND S. ŌshIRO, Weyl's theorem holds for p-hyponormal operators, Glasgow Math. J., 39 (1997), 217-220.

[6] M. CHO AND K. TANAHASHI, Spectral properties of log-hyponormal operators, Scientiae Mathematicae, 2 (1999), 1-8.

[7] M. CHO AND K. TANAHASHI, Isolated point of spectrum of p-hyponormal, log-hyponormal operators, preprint.

[8] M. FujII, R. NAKAmoto And H. WATANABE, The Heinz-Kato-Furuta inequality and hyponormal operators, Math. Japon., 40 (1994), 469-472.

[9] T. FuRUTA, On the class of paranormal operators, Proc. Japan Acad. 43 (1967), 594-598.

[10] T. FuRUTA, M. ITO AND T. YAMAZAKI, A subclass of paranormal operators including class of log -hyponormal and several related classes, Scientiae Math. 1 (1998), 389-403.

[11] T. FURUTA AND M. YANAGIDA, On powers of p-hyponormal and log -hyponormal operators, Sci. Math., 2 (1999), 279-284.

[12] F. HANSEN, An inequality, Math. Ann., 246 (1980), 249-250.

[13] E. HeINZ, Beiträge zur Störungstheorie der Spektralzerlegung, Math. Ann., 123 (1951), 415-438.

[14] V. IstrăţESCU, T. SAITô AND T. YoshinO, On a class of operators, Tôhoku Math. J. (2), 18 (1966), 410-413.

[15] Mi. Young. LeE AND SANG. Hun. LeE, Some generalized theorems on p-quasihyponormal operators for $0<p<1$, Nihonkai Math. J., 8 (1997), 109-115.

[16] K. LÖWNER, Über monotone Matrixfunktionen, Math. Z., 38 (1934), 177-216.

[17] J. G. STAMPFL, Hyponormal operators, Pacific J. Math., 12 (1962), 1453-1458.

[18] K. TANAHASHI, On log -hyponormal operators, Integral Equations and Operator Theory, 34 (1999), 364-372.

[19] K. TANAHASHI AND A. UCHIYAMA, Isolated point of spectrum of p -quasihyponormal operators, preprint.

[20] A. UCHIYAMA, Inequalities of Putnam and Berger-Shaw for p-quasihyponormal operators, Integral Equations and Operator Theory, 34 (1999), 91-106.

[21] A. UChIYAMA AND T. Yoshino, Weyl's theorem for $p$-hyponormal or $M$-hyponormal operators, Glasgow Math. J., (to appear). 
[22] A. UCHIYAMA, Weyl's theorem for class A operators, Mathematical Inequalities \& Applications, 1 (2001), 143-150.

[23] D. XIA, On the non-normal operators-semihyponormal operators, Sci. Sinica., 23 (1980), 700-713. 